\title{
In vitro trypanocidal activity of the Egyptian plant Schinopsis lorentizii against trypomastigote and amastigote forms of Trypanosoma cruzi
}

\author{
Khaled Rashed ${ }^{1}$, Daniele da Silva Ferreira ${ }^{2}$, Viviane Rodrigues Esperandim² ${ }^{2}$ Maria Gabriela Marçal $^{2}$, Breno Mumic \\ Sequeira $^{2}$, Lúzio Gabriel Bocalon Flauzino ${ }^{2}$, Wilson Roberto Cunha ${ }^{2 *}$ \\ ${ }^{1}$ Pharmacognosy Dept., National Research Centre, 33-El-Bohouth st. (former El-Tahrir st.)-Dokki, Giza, Egypt. ${ }^{2}$ Núcleo de Pesquisas em Ciências Exatas e \\ Tecnológicas da Universidade de Franca, Franca, São Paulo, Brazil.
}

\begin{tabular}{|c|c|}
\hline ARTICLE INFO & ABSTRACT \\
\hline Article history: & Chagas' disease is a chronic illness caused by the protozoan Trypanosoma cruzi. According to estimates, \\
\hline Received on: $17 / 02 / 2016$ & approximately 16-18 million people are infected in Latin American. Plant extracts exhibit a wide variety of \\
\hline Revised on: 07/04/2016 & secondary metabolites and can play an important role in the discovery of new compounds with biological \\
\hline Accepted on: 23/04/2016 & potential. The in vitro trypanocidal activity of the extracts obtained from six plant species collected in Egypt \\
\hline Available online: $28 / 06 / 2016$ & (Parkia africana, Parkia roxburgi, Lagerstromeia speciosa, Schinopsis lorentzii, Lagerstromeia indica, and \\
\hline Key words: & $\begin{array}{l}\text { Sapindus saponaria) was assayed against trypomastigote and amastigote forms of } T \text {. cruzi. The cytotoxic } \\
\text { activity of the most active extract was also evaluated by conducting MTT assays. S. lorentzii and } S \text {. saponaria }\end{array}$ \\
\hline $\begin{array}{l}\text { Egyptian medicinal plants, } \\
\text { trypanocidal activity, }\end{array}$ & $\begin{array}{l}\text { were the most active extracts against the trypomastigote form; } \mathrm{IC}_{50} \text { values were } 9.9 \text { and } 27.34 \mu \mathrm{g} / \mathrm{mL} \text {, } \\
\text { respectively. The } S \text {. lorentzii extract was also evaluated against the amastigote form (IC } 50 \text { was } 111.5 \mu \mathrm{g} / \mathrm{mL} \text { ). The }\end{array}$ \\
\hline $\begin{array}{l}\text { Trypanosoma cruzi, } \\
\text { phytoconstituents. }\end{array}$ & $\begin{array}{l}S \text {. lorentzii extract did not exhibit significant cytotoxic activity. The selectivity index value indicated that this } \\
\text { extract was highly selective for the parasite. The } S \text {. lorentzii and } S \text {. saponariaextracts exhibit trypanocidal } \\
\text { activity, probably as a result of the presence ofdifferent constituentsand their concentrations in the extracts. }\end{array}$ \\
\hline
\end{tabular}

\section{INTRODUCTION}

Neglected tropical diseases are a group of lethal diseases or disabling infections affecting more than a billion people worldwide. Poor populations living in rural areas and urban slums are at higher risk of infection. Therefore, people suffering from these diseases constitute an unattractive market to the private research sector (Schmidt et al., 2012). Seventeen neglected tropical diseases, including Chagas' disease, leishmaniasis, and African trypanosomiasis affect millions of people around the world. It is estimated an annual incidence of 28,000 cases of Chagas' disease in the region of the Americas, 6

* Corresponding Author

Wilson Roberto Cunha, Núcleo de Pesquisas em Ciências Exatas e Tecnológicas da Universidade de Franca, Franca, São Paulo, Brazil. Email:wilson.cunha@unifran.edu.br to 8 million people infected and approximately 12,000 deaths per year (WHO). Chagas' disease, also known as American trypanosomiasis, is caused by the intracellular obligatory parasite Trypanosoma cruzi, which is transmitted to humans and other mammals by hematophagous insects (Rocha et al., 2007). After infection, a short-term acute phase (4-8 weeks) with patent parasitemia that often goes undiagnosed is followed by a lifelong chronic phase that appears after a long latent period known as indeterminate form. The chronic phase of Chagas disease is characterized by scarce circulating parasites. These parasites cause symptomatic chronic cardiomyopathy and/or digestive symptoms in approximately $30 \%$ of Chagas disease patients (Marin-Neto et al., 2007; Campi-Azevedo et al., 2015). Although the discovery of Chagas' disease dates back to over one hundred years, the drugs that are currently available to treat infected individuals, Nifurtimox and benznidazole have serious drawbacks. 
These medications exhibit high toxicity and limited effect against different $T$. cruzi isolates and stages of the disease, which makes the discovery of novel pharmaceuticals a matter of utmost importance (Soeiro 2009; Andriani et al., 2011).In this context, natural sources such as plants, which contain various secondary metabolites, can play an important role in the discovery of new substances with biological potential (Schimidt et al., 2012).

In continuation of our previous works on the antiparasitic studies of Egyptian plants (Rashed et al., 2013a,b),we now report the evaluation of the in vitro trypanocidal activity of six Egyptian plant extracts against trypomastigote form of $T$. cruzi, which have not yet been described. Additionally, we have also assessed the trypanocidal activity against amastigote form of $T$. cruzi and cytotoxic activity against $\mathrm{LLCMK}_{2}$ cells of the most active plant extract.

\section{MATERIALAND METHODS}

\section{Plant material}

Parkia africana, Parkia roxburgi, Lagerstromeia speciosa, Schinopsis lorentzii, Lagerstromeia indica, and Sapindus saponariabarks were collected from the Al-Zohiriya Garden in Giza, Egypt, in May 2011.

All the plants were identified by Dr. Mohammed ElGebaly at the Department of Botany, National Research Centre (NRC), and by Mrs. Tereeza Labib, Consultant of Plant Taxonomy at the Ministry of Agriculture and director of the Orman Botanical Garden, in Giza, Egypt. A voucher specimen was deposited in the herbarium of the Al-Zohiriya Garden in Giza, Egypt.

\section{Preparation of the extracts}

Air-dried bark of the plants (280g) was extracted with methanol/distilled water 80:20 (v/v) several times (five times), at room temperature, by the maceration method. Each extract was concentrated under reduced pressure, to afford12 g, $14.5 \mathrm{~g}, 10.5 \mathrm{~g}$, $16 \mathrm{~g}, 11.5 \mathrm{~g}$, or $13 \mathrm{~g}$ ofdry (P. Africana, P. roxburgi, L. speciosa, $S$. lorentizii, L. indica and $S$. saponaria) extracts, respectively.

\section{Phytochemical analysis.}

Phytochemical screening of each extract was conducted according to the methods described by Yadav and Agarwala (2011).

\section{Parasites and Life cycle}

The $\mathrm{Y}$ strain of $T$. cruzi was used in the assays. This strain is characterized by thin forms and tropism for phagocytic mononuclear cells (Pereira da Silva and Nussenzweig, 1953). The Y strain of $T$. cruzi is routinely maintained by serial passages through BALB/c mice. The Ethics Committee for Animal Care of the University of Franca authorized all the experiments; all the experimental protocols were in accordance with the national and international accepted principles for laboratory animal use and care.

\section{Anti-trypomastigote assay}

The in vitro trypanocidal assay was undertaken by using the trypomastigote form of $T$. cruzi, obtained by culturing in $\mathrm{LLMCK}_{2}$ cell lineage (Macaca mulatta kidney cell). The cells were cultured in RPMI-1640 medium supplemented with Lglutamine $(2 \mathrm{mM}), \mathrm{NaHCO}_{3}(10 \mathrm{mM})$, penicillin $(100 \mathrm{U} / \mathrm{mL})$, streptomycin $(100 \mu \mathrm{g} / \mathrm{mL})$, and $5 \%$ inactivated fetal calf serum. The culture was kept in a 96-well microplate at $37^{\circ} \mathrm{C}$, under atmosphere of $5 \% \quad \mathrm{CO}_{2}$ and $95 \%$ humidity. Trypomastigotes obtained from the blood of infected animals (by cardiac puncture) at the parasitemic peak were added to the cell culture at a 5:1 ratio. After seven days, the culture supernatant was removed and centrifuged, and the free forms of the parasite were harvested for the tests. Each well was filled with $1 \times 10^{6}$ cells, which were counted with the aid of a Neubauer chamber. The samples were dissolved in dimethyl sulfoxide (DMSO) and added to the wells to give final concentrations of $12.5,25,50,100$, and $200 \mu \mathrm{g} / \mathrm{mL}$. The microplate was incubated at $37^{\circ} \mathrm{C}$ for $24 \mathrm{~h}$, and the biological activity was evaluated by direct quantification of the parasites in a Neubauer chamber. RPMI 1640 medium plus DMSO were used as negative control; Benznidazole was used as positive control. All the experiments were performed in triplicate. Results are expressed as mean $\pm \mathrm{SD}$.

\section{Anti-amastigote assay}

The anti-amastigote assays were developed in $\mathrm{LLCMK}_{2}$ cellcultures as described by Giorgio et al., 1998. The cells were cultured in RPMI 1640 medium supplemented with glutamine (2 $\mathrm{mM}), \mathrm{NaHCO}_{3}(10 \mathrm{mM})$, penicillin $(100 \mathrm{U} / \mathrm{mL})$,streptomycin $(100$ $\mu \mathrm{g} / \mathrm{mL}$ ), and $5 \%$ inactivated fetal bovine serum. The culture was kept in a 24-well microplate for $24 \mathrm{~h}$, at $37{ }^{\circ} \mathrm{C}$, in $5 \% \mathrm{CO}_{2}$ with $95 \%$ humidity. Each well was filled with $1 \times 10^{6}$ cells, which were counted by using a Neubauer chamber. After $24 \mathrm{~h}$, the trypomastigotes obtained from the cell culture were collected and centrifuged at $760 \mathrm{rpm}$ for $8 \mathrm{~min}$, at $12{ }^{\circ} \mathrm{C}$. The supernatant consisted of trypomastigotes, whereas the cells constituted the sediment. After a second centrifugation (at $3000 \mathrm{rpm}$ for $30 \mathrm{~min}$, at $\left.12^{\circ} \mathrm{C}\right)$, the trypomastigotes $\left(1 \times 10^{6}\right)$ were added to the culture, and the microplate was incubated for $48 \mathrm{~h}$. The extract was dissolved in dimethyl sulfoxide (DMSO) and added to the wells to give final concentrations of $12.5,25,50,100$, and $200 \mu \mathrm{g} / \mathrm{mL}$. After $96 \mathrm{~h}$ of incubation, the colorimetric assay was accomplished by the Giemsa-staining method. The infected cells were counted, and the percentage of parasitic reduction was determined by comparison with the negative control (DMSO 0.5\%).

\section{Cytotoxicity assay}

The $\mathrm{LLCMK}_{2}$ fibroblast cells were grown in RPMI 1640 medium supplemented with penicillin $(100 \mathrm{U} / \mathrm{mL})$, streptomycin $(100 \mu \mathrm{g} / \mathrm{mL})$, and $5 \%$ inactivated fetal calf serum, and maintained at $37^{\circ} \mathrm{C}$ in $5 \% \quad \mathrm{CO}_{2}$. A cell suspension was seeded at a concentration of $1 \times 10^{6}$ cells $/ \mathrm{mL}$ in a 96-well microplate containing RPMI 1640 medium. Thereafter, the cells were treated with $S$. lorentzii extract at different concentrations $(12.5,25,50$, 
100 , and $200 \mu \mathrm{g} / \mathrm{mL}$ ). The plates were incubated at $37^{\circ} \mathrm{C}$ for 24 and $96 \mathrm{~h}$. The biological activity was evaluated by using the MTT colorimetric method [MTT; 3-(4,5-dimethylthiazol-2-yl)-2,5diphenyltetrazolium bromide] in a microplate reader at $540 \mathrm{~nm}$. RPMI 1640 medium plus DMSO and RPMI 1640 medium were used as positive and negative controls, respectively. All the experiments were performed in triplicate. The percentage of cytotoxicity was determined by the formula: \% cytotoxicity= $\{1-[(\mathrm{Y}-\mathrm{N}) /(\mathrm{N}-\mathrm{P})]\} \times 100$, where $\mathrm{Y}=$ absorbance of the well containing cells and the extract at different concentrations; $\mathrm{N}=$ negative control; $\mathrm{P}=$ positive control. The selectivity index (SI) was determined for trypomastigotes as the ratio of $\mathrm{CC}_{50}$ toIC $\mathrm{I}_{50}$ values.

\section{Statistical analysis}

The statistical tests were performed with the Graphpad Prism (version 5.0) software. The data were statistically analyzed by one-way analysis of variance.

\section{RESULTS AND DISCUSSION}

The biological potential of medicinal plants as a source of new drugs deserves further exploration. The use of plant extracts or plant-derived chemicals to treat several diseases has stood the test of time. In recent years, there has been growing interest in the use of medicinal plants in both underdeveloped and developing countries - natural drugs have been reported to be safe, especially when compared to synthetic drugs (Abirami et al., 2012).

Table 1 lists the results obtained for the trypanocidal activity of the assayed plant extracts against $T$. cruzi trypomastigotes.

Table 1: In vitro trypanocidal activity of plant extracts against the trypomastigote form of T. cruzi.

\begin{tabular}{|c|c|c|c|c|c|c|}
\hline \multirow{2}{*}{$\frac{\mathscr{U}}{\tilde{E}}$} & \multicolumn{6}{|c|}{$\%$ lysis \pm S.D. / concentration $(\mu \mathrm{g} / \mathrm{mL})$} \\
\hline & 200 & 100 & 50 & 25 & 12,5 & $\underset{(\mu \mathrm{g} / \mathbf{m L})}{\mathrm{IC}_{50}}$ \\
\hline 1 & $69.5 \pm 1.0$ & $63.0 \pm 4.3$ & $50.7 \pm 4.9$ & $27.8 \pm 4.1$ & $32.6 \pm 2.1$ & 54.5 \\
\hline 2 & $44.4 \pm 2.5$ & $25.0 \pm 1.6$ & $21.6 \pm 1.6$ & $10.0 \pm 3.3$ & $6.1 \pm 0.9$ & $>200$ \\
\hline 3 & $46.0 \pm 3.1$ & $33.3 \pm 1.5$ & $24.8 \pm 0.9$ & $21.1 \pm 2.4$ & $5.8 \pm 1.8$ & $>200$ \\
\hline 4 & $97.8 \pm 1.0$ & $95.2 \pm 0.6$ & $73.9 \pm 4.3$ & $75.0 \pm 4.7$ & $55.4 \pm 1.0$ & 9.9 \\
\hline 5 & $61.3 \pm 3.1$ & $16.7 \pm 2.0$ & $9.7 \pm 1.3$ & $13.2 \pm 2.0$ & $0 \pm 0$ & 170.8 \\
\hline 6 & $92.3 \pm 0.6$ & $79.4 \pm 1.7$ & $61.3 \pm 3.1$ & $50.1 \pm 1.0$ & $30.5 \pm 1.7$ & 27.34 \\
\hline
\end{tabular}

1: Parkia africana exract, 2: Parkia roxburgi extract, 3: Lagerstromeia speciosa extract, 4: Schinopsis lorentizii extract, 5: Lagerstromeia indica extract, 6: Sapindus saponaria extract. Benznidazole (positive control): $\mathrm{IC}_{50=}$ $9.8 \mu \mathrm{g} / \mathrm{mL}$.

The anti-Trypanosoma cruzi activity of the extracts was assessed at concentrations of $12.5,25,50,100$, and $200 \mu \mathrm{g} / \mathrm{mL}$ for 24 hours. The trypanocidal activity was determined by comparing the count of trypomastigotes in each sample with the count of trypomastigotes in control groups. The $S$. lorentzii and the $S$. saponaria extracts were the most active against the $\mathrm{Y}$ strain of $T$. cruzi; $\mathrm{IC}_{50}$ was 9.9 and $27.34 \mu \mathrm{g} / \mathrm{mL}$, respectively. At $200 \mu \mathrm{g} / \mathrm{mL}$, $100 \mu \mathrm{g} / \mathrm{mL}$, and lower concentrations, the $S$. lorentzii extract provided 97\%, 95\%, and over $70 \%$ trypomastigote lysis, respectively.

Compared to the $S$. lorentzii and $S$. saponaria extracts, the $P$. Africana and $L$. indica extracts exhibited lower trypanocidal potential, with $\mathrm{IC}_{50}$ values of 54.5 and $170.8 \mu \mathrm{g} / \mathrm{mL}$, respectively, and $69 \%$ and $61 \%$ trypomastigotelysis, respectively. The $P$. Roxburgi and L. speciosa extracts did not display significant trypanocidal activity $\left(\mathrm{IC}_{50}>200 \mu \mathrm{g} / \mathrm{mL}\right)$.

According to Osório et al. (2007), plant extracts with $\mathrm{IC}_{50}<10 \mu \mathrm{g} / \mathrm{mL}, \mathrm{IC}_{50}>10 \mu \mathrm{g} / \mathrm{mL}$ and $<50 \mu \mathrm{g} / \mathrm{mL}, \mathrm{IC}_{50}>50$ $\mu \mathrm{g} / \mathrm{mL}$ and $<100 \mu \mathrm{g} / \mathrm{mL}$, and $\mathrm{IC}_{50}>100 \mu \mathrm{g} / \mathrm{mL}$ can be classified as highly active, active, moderately active, and non-active with regard to their antiprotozoal activity, respectively. Based on this classification, the $S$. lorentzii $\left(\mathrm{IC}_{50}=9.9 \mu \mathrm{g} / \mathrm{mL}\right.$ ) and the $S$. saponaria $\left(\mathrm{IC}_{50}=27.3 \mu \mathrm{g} / \mathrm{mL}\right)$ extracts are highly active and active, respectively. Flavonoids and triterpenes, classes of constituents of these extracts, have been shown to exhibit trypanocidal action (Uchiyama, 2009; Izumi et al., 2011) and may account for the observed activity.

Table 2 shows data concerning the activity of the $S$. lorentzii extract (the most active against $T$. cruzi trypomastigotes) against $T$. cruzi amastigotes. Compared with its activity against $T$. cruzi trypomastigotes, the $S$. lorentzii extract was less active against $T$. cruzi amastigotes: $\mathrm{IC}_{50}$ was $111.5 \mu \mathrm{g} / \mathrm{mL}$, and parasite lysis was around $60 \%$ and $44 \%$ at 200 and $100 \mu \mathrm{g} / \mathrm{mL}$, respectively. The lower susceptibility of amastigotes to the extract can be rationalized as follows: to gain access to the intracellular parasite (amastigote), the extract has to cross the host cell membrane and the parasitophorous vacuole membrane, whereas the extracellular trypomastigote is directly exposed to the extract.

Table 2: In vitro trypanocidal activity of plant extracts against the amastigote form of T. cruzi

\begin{tabular}{|c|c|c|c|c|c|c|}
\hline \multirow[b]{2}{*}{ Sample } & \multicolumn{6}{|c|}{$\%$ lysis \pm S.D./concentration $(\mu \mathrm{g} / \mathrm{mL})$} \\
\hline & 200 & 100 & 50 & 25 & 12,5 & $\begin{array}{c}\mathrm{IC}_{50} \\
(\mu \mathrm{g} / \mathrm{mL})\end{array}$ \\
\hline S. lorentizii & $\begin{array}{l}60.5 \pm 4 . \\
0\end{array}$ & $\begin{array}{l}44.4 \pm 0 . \\
6\end{array}$ & $\begin{array}{l}40.9 \pm 2 . \\
8\end{array}$ & $\begin{array}{l}27.5 \pm 3 \\
4\end{array}$ & $\begin{array}{l}19.1 \pm \\
1.7\end{array}$ & 111.5 \\
\hline
\end{tabular}

Positive Control: Benznidazole $\left(\mathrm{IC}_{50}=19.1 \mu \mathrm{g} / \mathrm{mL}\right.$ ); Negative Control: DMSO $0.5 \%$

MTT assays on $\mathrm{LLCMK}_{2}$ fibroblast cells allowed us to ascertain the cytotoxicity of the $S$. lorentzii extract; the assayed concentration range was chosen on the basis of in vitro studies conducted with $T$. cruzi. The cell cultures were treated with the extract at concentrations of $12.5,25,50,100$, and $200 \mu \mathrm{g} / \mathrm{mL}$ for 24 and 96 hours. Cell viability was determined by the ratio between the absorbance values obtained in the treated and untreated (control) groups (Fig. 1).

The $S$. lorentzii extract was not significantly cytotoxic to LLCMK $_{2}$ cells within the first 24 hours of the experiment:CC $C_{50}$ was greater than $400 \mu \mathrm{g} / \mathrm{mL}$, and cell viability remained around $79 \%$ at the highest tested concentration. Similarly, after 96 hours of treatment, $\mathrm{CC}_{50}$ was greater than $400 \mu \mathrm{g} / \mathrm{mL}$, and the percentage 
of viable cells was around $78 \%$ at the higher assayed concentrations (400 and $200 \mu \mathrm{g} / \mathrm{mL}$ ).

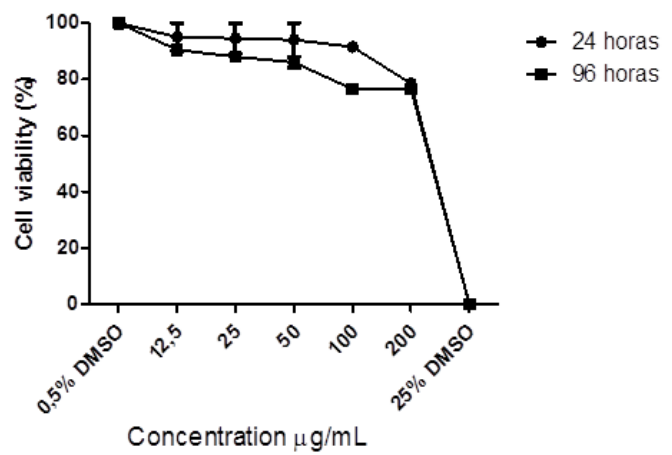

Fig. 1: Effects of $S$. lorentizii extract on the viability of $\mathrm{LLCMK}_{2}$ fibroblast cells. Cytotoxicity was determined by the MTT assay after 24 and $96 \mathrm{~h}$ of treatment with the indicated concentrations. Values are expressed as mean \pm S.D.

The selectivity index represents the selectivity of a compound for a parasite cell and for a normal cell line. This index indicates the potential use of a given compound in clinical trials. To compare the trypanocidal activity and the toxicity of the $S$. lorentzii extract, we used mammalian cells to estimate the selectivity index (SI) of this extract. According to Lenta et al. (2007), SI values greater than 10 suggest that a compound is safe for use in mammals. The S. lorentzii extract gave SI of 40, which indicated that it was highly selective for the parasite.

Table 3: Results of the phytochemical screening of the plant extracts.

\begin{tabular}{|c|c|c|c|}
\hline Botanical name & Plant Family & Plant part & Phytoconstituints \\
\hline Parkia africana & Leguminoseae & Bark & $\begin{array}{l}\text { Triterpenes/Sterols } \\
\text { Carbohydrates/ } \\
\text { glycosides } \\
\text { Flavonoids } \\
\text { Tannins }\end{array}$ \\
\hline Parkia roxburgi & Leguminoseae & Bark & $\begin{array}{l}\text { Triterpenes/Sterols } \\
\text { Carbohydrates/ } \\
\text { glycosides } \\
\text { Flavonoids } \\
\text { Tannins }\end{array}$ \\
\hline $\begin{array}{l}\text { Lagerstromeia } \\
\text { speciosa }\end{array}$ & Lythraceae & Bark & $\begin{array}{l}\text { Triterpenes/Sterols } \\
\text { Carbohydrates/ } \\
\text { glycosides } \\
\text { Flavonoids } \\
\text { Tannins }\end{array}$ \\
\hline Schinopsis lorentizii & Anacardiaceae & Bark & $\begin{array}{l}\text { Triterpenes/Sterols } \\
\text { Carbohydrates/ } \\
\text { glycosides } \\
\text { Flavonoids } \\
\text { Tannins }\end{array}$ \\
\hline Lagerstromeia indica & Lythraceae & Bark & $\begin{array}{l}\text { Triterpenes/Sterols } \\
\text { Carbohydrates/ } \\
\text { glycosides } \\
\text { Flavonoids } \\
\text { Tannins }\end{array}$ \\
\hline Sapindus saponaria & Sapindaceae & Bark & $\begin{array}{l}\text { Triterpenes/Sterols } \\
\text { Carbohydrates/ } \\
\text { glycosides } \\
\text { Flavonoids } \\
\text { Tannins } \\
\text { Saponins }\end{array}$ \\
\hline
\end{tabular}

The phytochemical analyses of the investigated plant extracts showed the presence of triterpenes, flavonoids, tannins, and carbohydrates; the $S$. saponaria extract also contained saponins (Table 3). Several studies have reported on the trypanocidal activity of natural flavonoids (Takeara et al., 2003; Sulsen et al., 2007; Mai et al., 2015). The lyophilized aqueous extract from Lychnophora pinaster Mart (Asteraceae) exhibits trypanocidal action $(113.62 \mu \mathrm{g} / \mathrm{mL})$; chemical characterization of this extract by HPLC revealed the presence of caffeic acid, isochlorogenic acid, vitexin, isovitexin, and quercetin (Silveira et al., 2005).

Flavonoids like hispidulin and santin have significant trypanocidal and leishmanicidal activities. These flavonoids could serve as potential lead compounds for the development of more efficient drugs to treat leishmaniasis and Chagas disease (Sulsen et al., 2007).

Terpenoids are a class of natural substances with various biological applications (Roberts, 2007). Their in vitro and in vivo trypanocidal potential has been extensively studied (Duarte et al., 2002; Rosas et al., 2007; Ferreira et al., 2013).

Recently, Santos et al. (2013) have described the leishmanicidal and trypanocidal activities of two triterpenes, maytenin and pristimerin, isolated from Maytenus ilicifolia. The compounds are effective against Leishmania amazonensis and Leishmania chagasias well as Trypanosoma cruzi. Both compounds have $\mathrm{IC}_{50}$ lower than $0.3 \mathrm{nM}$ against $T$ cruzi epimastigotes.

Oleanolic and ursolic acids are ubiquitous triterpenoids in the plant kingdom, particularly in medicinal herbs, and are an integral part of the human diet. Previous studies reported by our group have shown that these triterpenes display significant in vitro trypanocidal activity (Cunha et al., 2003, Cunha et al., 2006; Ferreira et al., 2010).

The industrial applications and properties of vegetable tannins stem from their ability to form complexes with proteins via hydrogen bonds. Tannins can inhibit microorganism growth by irreversibly deactivating enzymes (Venter et al., 2012). These compounds exhibit leismanicidal and trypanocidal activities (Kolodziej and Kiderlen, 2005; Ogbadoyi et al., 2007).

Shuaibu et al. (2008) have reported on the in vitro antitrypanosomal activity of Anogeissus leiocarpus and Terminalia avicennoides methanolic extracts against four Trypanosoma species strains. Hydrolyzable tannins present in these extracts display trypanocidal action ( $\mathrm{MIC}=7.5-27.5 \mu \mathrm{g} / \mathrm{mL}$ or $14-91 \mu \mathrm{M}$ ). Moreover, these compounds are not significantly toxic to fibroblasts.

Cejas et al. (2011) authored one of the few literature studies on the antiparasitic activity of $S$. lorentzii. More specifically, these authors evaluated whether a commercially available polyphenolic vegetable extract from $S$. lorentzii (Bioquina $^{\circledR}$ ) reduced coccidiosis in broiler chicks. These authors suggested that the extract may have an impact against avian coccidiosis, but they stated that further studies on the potential 
value of this product as a therapeutic or prophylactic anticoccidial agent are necessary.

According to Barberis et al. (2012), the species of the genus Schinopsis have numerous applications, especially in animal husbandry and cattle ranching as well as logging activities. Several authors have reported that species of this genus contain phenols that can control gastrointestinal parasites in ruminants and rodents (Paolini et al., 2003; Max et al., 2005; Athanasiadou et al., 2007). Moreover, tannins present in S. lorentzii can also reduce helminths in birds (Marzoni et al., 2005). Thus, the tannins identified in the most active extracts of the present study could also account for the antiparasitic activity displayed by these extracts.

Given the important limitations of the currently available treatment for Chagas disease, especially the low efficacy of the medication in the chronic phase, new steps have been taken toward the search for chemotherapeutic approaches that can improve the control of this disease (Urbina, 2010).

Investigations into natural products can potentially provide positive results, particularly in the case of diseases that are difficult to treat and for which there is no cure. Determining the efficacy or optimum concentration of a tested drug is extremely important and acquiring information about its effect on parasite biology and parasite interaction with the host cell is of great value (Maya et al., 2007).

\section{CONCLUSION}

This work has demonstrated the trypanocidal activity of $S$. lorentzii on the two evolutive forms of $T$. cruzi for the first time. The trypanocidal activity observed for the extracts of $S$. lorentzii and $S$. saponariacan be result of the presence of different constituents and their concentrations in the extracts. The low toxicity of the $S$. lorentzii extract to mammalian cells associated with its significant trypanocidal action makes this extract a promising candidate for the discovery of new trypanocidal drugs. Further studies on the isolation, identification, and bioassays of active compounds against the trypomastigote and amastigote forms of $T$. cruzi and in vivo assays are essential to elucidate structure-activity relationships, unveil the mechanisms of parasite death induced by the most promising substances, and identify their putative intracellular targets. Hopefully, such studies will culminate in the development of novel therapeutic agents to treat Chagas' disease.

Conflict of Interest Statement: The authors report no conflicts of interest. The authors alone are responsible for the content and writing of the paper.

\section{ACKNOWLEDGEMENTS}

The authors thank CAPES, FAPESP and CNPq for the fellowships.

\section{REFERENCES}

Abirami P, Gomathinayagam M, Panneerselvam R. Preliminary study on the antimicrobial activity of Enicostemmalittorale using different solvents. Asian Pac J Trop Med,2012; 5:552-555. Andriani G, Chessler A-DC, Courtemanche G, Burleigh BA, Rodriguez A.Activity in vivo of anti-Trypanosomacruzi compounds selected from a high throughput screening. PLoS Negl Trop Dis, 2011; $5: 1-6$.

Athanasiadou S, Githiori J, Kyriazakis I. Medicinal plants for helminth parasite control: facts and fiction. Animal, 2007; 1:1392-1400.

Barberis IM, Mogni V, Oakley L, Alzugaray C, Vesprini JL, Prado DE. Biología de especies australes: Schinopsis balansae Engl. (Anacardiaceae). Kurtziana,2012; 37:59-86.

Campi-Azevedo AC, Gomesa JAS, Teixeira-Carvalho A, Silveira-Lemos D, Vitelli-Avelar DM, R Sathler-Avelar, PeruhypeMagalhães V, Béla SR, Silvestre KF, Batista MA, Schachnik NCC, Correa-Oliveira R, Eloi-Santos SM, Martins-Filho OA. Etiological treatment of Chagas disease patients with benznidazolelead to a sustained pro-inflammatory profile counterbalanced bymodulatory events. Immunobiology, 2015; 220:564-574.

Cejas E, Pinto S, Prosdócimo F, Batallé M, Barrios H, Tellez G, Franceschi M. Evaluation of quebracho red wood (Schinopsis lorentzii) polyphenolic vegetable extract for the reduction of coccidiosis in broiler chicks. Int J Poult Sci, 2011; 10:344-349.

Cunha WR, Crevelin EJ, Arantes GM, Crotti AE, Silva MLA, Furtado NA, Ferreira DS. A study of trypanocidal activity of triterpene acids isolated from Miconia species. Phytother Res, 2006; 20:474-478.

Cunha, WR, Martins C, Ferreira DS, Crotti, AEM, Lopes NP, Albuquerque S. In vitro trypanocidal activity of triterpenes from Miconia species. Planta Med, 2003;69:468-470.

Duarte LP, Vieira Filho SA, Silva GDF, Sousa JR, Pinto AS. Anti-trypanosomalactivityofpentacyclictrierpenesisolated

fromAustroplenckia populnea (Celastraceae). Rev Inst Med Trop São Paulo, 2002; 44:109-112.

Ferreira DS, Esperandim VR, Marçal MG, Neres NBR, Cunha NL, Silva MLA, Cunha WR.Natural products and Chagas' disease: the action of triterpenes acids isolated from Miconia species. Univ Sci, 2013; $18: 243-256$.

Ferreira DS, Esperandim VR, Toldo MPA, Saraiva J, Cunha WR, Albuquerque S. Trypanocidal activity and acute toxicity assessment of triterpene acids. Parasitol Res, 2010; 106:985-989.

Giorgio S, Barão SC, Augusto O, Kwee JK. Leishmania amazonensis infection is reduced in macrophages treated with guanine ribonucleosides. Acta Trop, 1998; 70:119-122.

Izumi $\mathrm{E}$, Ueda-Nakamura $\mathrm{T}$, Filho $\mathrm{BPD}$, Júnior VFV, Nakamura CV. Natural products and Chagas disease: a review of plant compounds studied for activity against Trypanosoma cruzi. Nat Prod Rep,2011;28:809-823.

Kolodziej H, Kiderlen AF. Antileishmanial activity and immune modulatory effects of tannins and related compounds on Leishmania parasitised RAW 264.7 cells. Phytochemistry, 2005; 66:2056-71.

Lenta BN, Vonthron-Senecheau CR, Sohd F,Tantangmo F, Ngouela S, Kaiser M, Tsamo E, Anton R, Weniger B. In vitro antiprotozoal activities and cytotoxicity of some selected Cameroonian medicinal plants. J Ethnopharmacol, 2007; 111:8-12.

Mai LH, Chabot GG, Grellier P, Quentin L, Dumontet V, Poulain C, Espindola LS, Michel S, Vo HTB, Deguin B, Grougnet R. Antivascular and anti-parasite activities of natural and hemisynthetic flavonoids from New Caledonian Gardenia species (Rubiaceae). Eur J Med Chem, 2015; 93:93-100.

Marin-Neto JA, Rassi Jr A, Morillo CA, Avezum A, Connolly SJ, Sosa-Estani S, Rosas F, Yusuf, S. Rationale and design of a randomized placebo-controlled trial assessing the effects of etiologic treatment in Chagas' cardiomyopathy: the benznidazole evaluation for interrupting trypanosomiasis. Am Heart J, 2007;156:38-43. 
Marzoni M, Castillo A, Romboli I. Dietary inclusion of Quebracho (Schinopsis lorentzii) tannins on productive performances of growing pheasant females. Ital J Anim Sci, 2005, 4:507-509.

Max RA, Wakelin D, Craigon J, Kassuku AA, Kimambo AE, Mtenga LA, Buttery, PJ. Effect of two commercial preparations of condensed tannins on the survival of gastrointestinal nematodes of mice and goats in vitro. S Afr J Anim Sci, 2005; 35:213-220.

Maya JD, Cassels BK, Iturriaga-Vásquez P, Ferreira J, Faundez M, Galanti N, Ferreira A, MORELLO A. Mode of action of natural and synthetic drugs against Trypanosomacruzi and their interaction with the mammalian host. Comp Biochem Phys A, 2007; 146:601-20.

Ogbadoyi EO, Abdulganiy AO, Adama TZ, Joseph IO. In vivo trypanocidal activity of Annona senegalensis Pers. leaf extract against Trypanosoma brucei brucei. J Ethnopharmacol, 2007; 112:85-89.

Osorio E, Arango GJ, Jiménez N,Ruiz G, Gutiérrez D, Paco MA, Giménez A, Robledo S. Antiprotozoal and cytotoxic activities in vitro of Colombian Annonaceae. J Ethnopharmacol, 2007; 111:630-635.

Paolini V, Bergeaud JP, Grisez C, Prevot F, Dorchies P, Hoste H. Effects of condensed tannins on goats experimentally infected with Haemonchus contortus. Vet Parasitol, 2003; 113:253-261.

Pereira da Silva LH, Nussenzweig V. Sobre uma cepa de Trypanosoma cruzi altamente virulenta para o camundongo branco. Folia ClinBiol, 1953;20:191-208.

Rashed K, Da Cruz MG, Souza JM, Cunha WR, Magalhães LG.Evaluation of schistomicidal and leishmanicidal activities from Alnus rugosa (L.) and phytochemical composition. IJIPSR, 2013a; 1:227-234.

Rashed K, Da Cruz MG, Souza JM, Magalhães LG, Cunha WR.Evaluation of schistomicidal and leishmanicidal activities from Dodonaeae viscosa (L.) and phytochemical profile. Int J Inv Pharm Sci, 2013b; 1:462-466.

Roberts, SC. Production and engineering of terpenoids in plant cell culture. Nat Chem Biol, 2007; 3:387-395.

Rocha MO, Teixeira MM, Ribeiro AL.An update on the management of Chagas cardiomyopathy.Expert RevAntiInfectTher, 2007; 5:727-743.

Rosas LV, Cordeiro MSC, Campos FR, et al. In vitro evaluation of the cytotoxic and trypanocidal activities of Ampelozizyphus amazonicus (Rhamnaceae). Braz J Med Biol Res, 2007; 40:663-670.

Santos VAFFM, Leite KM, Siqueira MC, Regasini LO, Martinez I, Nogueira CT, Galuppo MK, Stolf BS, Pereira AMS, Cicarelli RMB, Furlan M, Graminha MAS. Antiprotozoal activity of quinonemethide triterpenes from Maytenus ilicifolia (Celastraceae). Molecules, 2013; 18:1053-1062.

Schmidt TJ, Khalid SA, Romanha A,Alves TMA, Biavatti MW, Brun R, Da Costa FB, de Castro SL, Ferreira VF, de Lacerda MVG, Lago JHG, Leon LL, Lopes NP, das Neves Amorim RC, Niehues M, Ogungbe IV, Pohlit AM, Scotti MT, Setzer WM, Soeiro MNC, Steindel M, Tempone AG. The potential of secondary metabolites from plants as drugs or leads against protozoan neglected diseases - Part I. Curr Med Chem, 2012;19:2128-2175.
Shuaibu MN, Wuyep PT, Yanagi T, Hirayama K, Ichinose A, Tanaka T, Kouno I.Trypanocidal activity of extracts and compounds from the stem bark of Anogeissus leiocarpusand Terminaliaavicennoides. Parasitol Res, 2008;102:697-703.

Silveira D, Wagner H, Chiari E, Lombardi JA, Assunção AC, de Oliveira AB, Raslan DS. Biological activity of the aqueous extract of Lychnophora pinaster Mart. Rev BrasFarmacogn, 2005; 15:294-297.

Soeiro MNC, de Castro SL. Trypanosoma cruzi targets for new chemotherapeutic approaches. Expert Opin Ther Targets, 2009; 13:105121.

Sülsen VP, Cazorla SI, Frank FM, Redko FC, Anesini CA, Coussio JD, Malchiodi EL, Martino VS, Muschietti LV. Trypanocidal and leishmanicidal activities of flavonoids from Argentine medicinal plants. Am J Trop Med Hyg, 2007; 77:654-659.

Takeara R, Albuquerque S, Lopes NP. Trypanocidal activity of Lychnophora staavioides Mart. (Vernonieae, Asteraceae). Phytomedicine, 2003; 10:490-493.

Uchiyama N. Antichagasic activities of natural products against Trypanosoma cruzi.J Health Sci, 2009; 55:31-39.

Urbina JA. Specific chemotherapy of Chagas' disease: Relevance, current limitations and new approaches. Acta Trop, 2010; 115:55-68.

Venter PB, Senekal ND, Amra-Jordaan M, Bonnet SL, Van der Westhuizen JH. Analysis of commercial proanthocyanidins. Part 2: An electrospray mass spectrometry investigation into the chemical composition of sulfited quebracho (Schinopsis lorentzii and Schinopsis balansae) heartwood extract. Phytochemistry, 2012; 78:156-169.

World Health Organization: Available at: http://www.paho.org/hq/index.php?option=com_topics\&view=article\&id= 10\&Itemid=40743 [Accessed 23 November 2015].

Yadav RNS, Agarwala M.Phytochemical analysis of some medicinal plants. J Phytol, 2011; 3:10-14.

\section{How to cite this article:}

Rashed K, Ferreira DDS, Esperandim VR, Marçal MG, Sequeira BM, Flauzino LGB, Cunha WR. In vitro trypanocidal activity of the Egyptian plant Schinopsis lorentizii against trypomastigote and amastigote forms of Trypanosoma cruzi. J App Pharm Sci, 2016; 6 (06): 055-060. 